\section{Corporate Governance of Banks in Poland and Slovenia}

\section{Polona Pašić}

PhD Student at the Faculty of Economics and Business, University of Maribor, Slovenia

polona.pasic@gmail.com

\section{Borut Bratina}

Faculty of Economics and Business, University of Maribor, Slovenia borut.bratina@um.si

\section{Mejra Festić}

Bank of Slovenia, Ljubljana, Slovenia ${ }^{1}$

mejra.festic@bsi.si

\begin{abstract}
This paper focuses on the analysis of the characteristics of corporate governance in banks in Poland and Slovenia between 2005 and 2013. It studies the impact of corporate governance in these banks on their performance. The results of our research show that Slovenia achieved lower average scores for the variables and indicators related to the transparency of corporate governance than Poland. The density of banks with the highest corporate governance index scores was higher in Poland than in Slovenia. When examining the impact of corporate governance on bank performance as measured with net interest income, the regression analysis showed that its impact is positive in both countries and that it is statistically significant in Slovenia.
\end{abstract}

Key words: corporate governance, bank performance, Central and Eastern Europe, corporate governance index, net interest income

\section{Introduction}

During the financial crisis that began in 2007, it became clear that corporate governance had not functioned as expected. Adams and Mehran (2008) argued that bad corporate governance played a significant role in this crisis. The information about risk exposure was not always forwarded to bank boards or even to top executives, the risks were often managed on a short-term rather than on a long-term basis, and the remuneration and incentive systems also encouraged a short-term orientation (Kirkpatrick, 2009).

The banking sector experienced a number of corporate governance-related weaknesses, which can destabilize entire financial systems and create systemic risks in economic systems. Caprio and Levine (2002) stated that banks' corporate governance is important not only for banks, but also for the entire economy. Even more, banks' corporate governance is crucial for growth and development (Levine, 2004).

\footnotetext{
1 The views expressed in this paper do not reflect the views of Bank of Slovenia or its authorities.
}

ORIGINAL SCIENTIFIC PAPER

RECEIVED: JUNE 2016

REVISED: AUGUST 2016

ACCEPTED: AUGUST 2016

DOI: 10.1515/ngoe-2016-0013

UDK: 336.71(438)(497.4)

JEL: G21, G34, G38

Citation: Pašić, P., Bratina, B., \& Festić, M. (2016). Corporate Governance of Banks in Poland and Slovenia. Naše gospodarstvo/Our Economy, 62(3), 3-12. DOI: 10.1515/ngoe-2016-0013

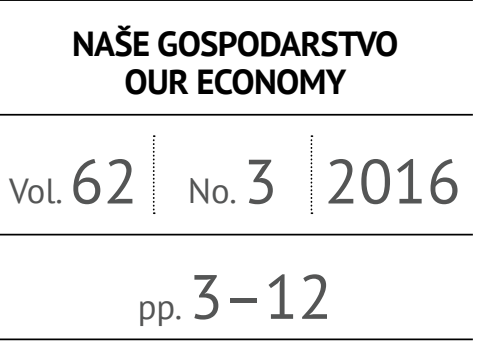


Banks' business operations differ from other organizations' business operations, which is also reflected in their governance practices. Regardless of that, both banks and other types of organizations are primarily expected to be safe and reliable institutions, and good-quality governance plays a significant role in this respect.

This paper analyzes the corporate governance of banks in Poland and Slovenia for 2005 to 2013. The purpose of the paper is to identify the characteristics of corporate governance of the analyzed banks and to investigate the impact of corporate governance on the banks' performance. The paper is divided into five parts. The first part provides theoretical foundations for the topic under discussion. The second and third parts are concerned with the research methods employed in this study and the empirical analyses. In the fourth part, key findings of our research are presented. Finally, the findings are discussed and summarized, and suggestions for future research are given.

\section{Theoretical Foundations and Literature Review}

As corporate governance is very topical, a number of research papers and books have recently been published covering this topic. In such research, authors have mainly addressed corporate governance in non-banking organizations, whereas corporate governance of banks has received less scholarly attention. Despite this, the existing research about corporate governance in banks adequately shows the state of affairs in corporate governance in banks and how it follows the principles of corporate governance applied in the non-banking sector.

The efficient corporate governance practices in banks are significant for gaining and retaining public trust in the banking system, which is, in turn, crucial for an adequate functioning of the banking system and the economy as a whole. Apart from the responsibilities toward shareholders, banks are also responsible to their depositors and other shareholders (Basel Committee on Banking Supervision, 2010).

The scope of corporate governance in banks is significantly broader than in other business organizations on the market (Arhar, 2008). The key question that arises in relation to banks' corporate governance is related to the quality of legislation, with the main issue being that this legislation is often inadequate. Tomasic (2010) pointed out that new foundations for the establishment of new legislation structures and governance strategies have to be established as a result of the crisis and that these foundations should unquestionably be international. According to Alexander (2010), efficient supervision and legislative regulations require banks to have robust corporate governance arrangements that encourage bank managers and bank owners to understand the risks they are taking and the implications these risks have for the shareholders if any costs related to such risks have to be covered. They should also be aware of any social costs on the broader economy if the bank fails. Alexander (2010) stated that corporate governance plays a significant role in this respect mainly by (i) aligning the incentives of bank owners and managers so that managers seek wealth maximization for owners without jeopardizing the bank's franchise value through excessive risk-taking and (ii) incentivizing bank management to price financial risk in such a way that it covers its social costs.

Curtiss, Levine, and Browning (2010) maintained that the reform of regulations and government reform should play a key role in ensuring stricter standards regarding capital adequacy, transparency, and remuneration policies. In addition, control over the role of credit rating agencies and auditors is needed in order to find ways to improve their quality and efficiency.

The first guidelines for the corporate governance of banks (i.e., Enhancing Corporate Governance for Banking Organisations) were issued in 1999 by the Bank for International Settlements and were first revised in 2006 (Basel Committee on Banking Supervision, 2006). Their aim was to offer assistance to bank supervisors and serve as the basis for the promotion of good practice of corporate governance of banking institutions in individual countries. The 2006 guidelines were founded on corporate governance principles issued by the OECD in 2004.

Due to all shortcomings of corporate governance practice that became evident during the financial crisis that started in 2007, the Basel Committee on Banking Supervision decided to revise the existing corporate governance guidelines. The revision showed that the guidelines are still relevant and that it is very important that their implementation be efficient.

The impact of corporate governance on bank performance has been studied extensively. For example, Love and Rachinsky (2007) researched the general impact of corporate governance on bank performance. Based on a sample of banks from Ukraine, they found that better corporate governance is linked to higher ROA, ROE, and net interest income. They also established a significant causality between corporate governance and ROA, ROE, and a lower proportion of non-performing loans (NPL) in Russia. Utama and Musa (2011) also studied the correlation between corporate governance practices and bank performance. They found that corporate governance has a positive impact on bank performance as expressed in ROA, while bank performance does not influence corporate governance practice. Selvaggi and Upton (2008) established that the number of years 
during which a company experiences corporate governance problems is negatively related to company performance; the causality between good corporate governance and successful performance is strong, whereas the opposite is not true. The results of Guo, Langston, and Hadley's (2012) study support the hypothesis that bank performance and the quality of assets are related to different corporate governance variables for different stages of the business cycle. The researchers also stated that some features of corporate governance are suitable for a certain industry due to specific characteristics of that industry, but they may not be good for other industries. Thus, the results of the research on corporate governance within one industry should not be compared with or among different industries (Guo et al., 2012).

La Porta, Lopez-de-Silanes, Shleifer, and Vishny (1998) established that financial transparency and disclosures of adequate information are crucial for corporate governance. To guarantee the transparency and quality of disclosures, the use of adequate accounting standards and efficient legislation is needed too; that is, the timely disclosure of adequate and credible information enables shareholders to have control and discipline managers. Companies with higher disclosure quality suffer less during a financial crisis (Baek, Kang, \& Park, 2004). The transparency of business operations and the disclosure of adequate information are even more important for banks because banks have an influence on the entire financial system.

Słomka-Gołębiowska and Urbanek (2014) stated that transparency is one of the most significant attributes of good corporate governance. Thus, transparency strengthens the confidence in the capital market. In addition, shareholders and other stakeholders have the right to full information concerning the bank.

Lloyd (2009) found that the last financial crisis can be seen as a consequence of bad corporate governance, which points to the fact that board members had not responded adequately to the occurrence of financial risks. In return, the non-functioning of corporate governance mechanisms manifested in companies’ performance.

\section{Methods}

This paper presents a comprehensive view on corporate governance by supplementing and extending the existing methodological approaches to the study of corporate governance of banks. Our research included a number of variables that define corporate governance in banks. We deducted the characteristics and quality of corporate governance of banks by assessing their disclosure and transparency in the annual reports. We then linked these observations to the banks' performance and examined if causality exists between banks' corporate governance and their performance.

The independent variables of corporate governance were logically organized and grouped into corporate governance indicators. In our research, we addressed the following five indicators: (i) commitment to corporate governance (CG), (ii) control and audit, (iii) care for stakeholders, (iv) characteristics of supervisory board and management board, and (v) remuneration, ownership, related-party transactions, and the application of IFRS.

All statistical analyses of data were performed using EViews and Microsoft Office Excel.

\subsection{Data collection}

Data for our analysis were collected as follows. We first set up a matrix based on the pre-determined parameters (variables) studied in our research. Then, we collected the relevant data from the banks' annual reports based on the analysis and assessment of the disclosure of individual features of corporate governance. We accessed these annual reports mainly via the banks' websites.

Regarding the individual variables constituting corporate governance indicators, the banks could get a maximum score of 1 and a minimum score of 0 per variable, whereby 1 indicated high quality or the presence of the disclosure of information in relation to the specific corporate governance characteristic and 0 indicates low quality or non-presence. For some variables, scores of 0.5 and 0.25 were also possible. The sums of individual variables represent the scores of the indicators they constitute. The aggregate sums of the variables in these indicators comprise the corporate governance index. For the needs of the regression analysis, we rescaled the index scores so that the standardized index scores had a mean of 0 and a standard deviation of 1 . The rescaling and the calculations as well as the subsequent analysis of data and the study of corporate governance and its impact on bank performance were carried out for Slovenia and Poland, separately. We measured bank performance using the banks' net interest income (NETII). We obtained data on this financial indicator from the Bankscope database. For the purposes of our research, we extracted the financial data for the banks in our sample for 2005 to 2013.

\subsection{Sample}

Slovenia and Poland are part of Central and Eastern Europe and have been members of the EU since 2004. The two 
countries are located in geographically similar areas and are mutually comparable. However, there are also differences between them in regard to companies' business operations. The role and cooperation between the participants of corporate governance differ between these two countries because they depend on the legislation and regulatory measures as well as partly on voluntary decisions and, most importantly, market conditions (Organisation for Economic Cooperation and Development, 2009).

Our sample consisted of the 10 largest banks (per their balance-sheet assets in 2005) from Slovenia and Poland. We studied their performance from 2005 to 2013. We decided to examine this time period because of its characteristicsnamely, during these years, a big financial and economic crisis occurred (starting in 2007 and intensifying in 2008). Also, the data for this time period were readily available in most cases.

\section{Key Findings}

\subsection{Characteristics of the Countries and Banks Under Analysis}

Table 1 shows the gross domestic product (GDP) per market prices (in EUR per capita) for Poland, Slovenia, and the European Union. Both countries have a lower GDP per capita than the EU average (27 member states), with Slovenia having a higher GDP than Poland.

Table 2 presents the number and size of credit institutions in Poland and Slovenia from 2007 to 2013. The number of credit institutions was significantly higher in Poland than in Slovenia throughout the time period. The size of credit institutions determined by the total assets of banks (in EUR million) on the last day of the year was bigger in Poland and was increasing throughout the 2007-2013 period.

Reforms of the Polish banking system have been rather slow. They were based on a decentralized restructuring program founded on the change of the incentives for banks and the real economy and which contributed to harsh budgetary constraints in the Polish economy (Pawłowska, 2014). Between
Table 2. Number and Size of Credit Institutions, 2007-2013

\begin{tabular}{|c|c|c|c|}
\hline Year & Credit institutions & Poland & Slovenia \\
\hline \multirow{2}{*}{2007} & Number & 645 & 24 \\
\hline & Total assets & 220,621 & 42,208 \\
\hline \multirow{2}{*}{2008} & Number & 649 & 21 \\
\hline & Total assets & 250,825 & 47,345 \\
\hline \multirow{2}{*}{2009} & Number & 643 & 22 \\
\hline & Total assets & 257,382 & 51,328 \\
\hline \multirow{2}{*}{2010} & Number & 646 & 22 \\
\hline & Total assets & 292,745 & 50,244 \\
\hline \multirow{2}{*}{2011} & Number & 640 & 22 \\
\hline & Total assets & 293,134 & 48,592 \\
\hline \multirow{2}{*}{2012} & Number & 642 & 21 \\
\hline & Total assets & 336,034 & 45,352 \\
\hline \multirow{2}{*}{2013} & Number & 640 & 20 \\
\hline & Total assets & 339,153 & 39,455 \\
\hline
\end{tabular}

Source:European Banking Authority (2015)

1995 and 2000, the proportion of banks in Poland under foreign ownership increased substantially from $4.2 \%$ to $69.5 \%$, while the proportion of state-owned banks dropped considerably from $86.2 \%$ to $23.9 \%$ (Pawłowska, 2014). Poland has a two-tier governance system with a supervisory board and a management board. There is a high level of foreign ownership of companies. It is not necessary to have a representative of employees on the supervisory board. Polish business law is similar to the one in Austria and in Germany. Also, there is usually a high concentration of ownership and few disclosures of variable remuneration. The ROSC report (The World Bank, 2005) identified numerous problems related to corporate governance in Poland: (i) insufficient regulation of corporate governance activities related to pension funds, (ii) weakness of the supervisory board, (iii) problems in the delisting/squeeze-out process, and (iv) insufficient approvals of related party transactions. In their research, Słomka-Gołębiowska and Urbanek (2014) established that the low transparency of reporting and poor disclosures make it impossible or at least difficult to assess if banks work in compliance with the corporate governance recommendations.

Table 1. Gross Domestic Product per Market Prices (in EUR per capita)

\begin{tabular}{lrrrrrrrrr} 
Country/Year & 2005 & 2006 & 2007 & 2008 & 2009 & 2010 & 2011 & 2012 & 2013 \\
\hline Poland & 6,400 & 7,100 & 8,200 & 9,500 & 8,100 & 9,200 & 9,600 & 9,900 & 10,100 \\
\hline Slovenia & 14,400 & 15,500 & 17,100 & 18,400 & 17,400 & 17,400 & 17,600 & 17,200 & 17,100 \\
\hline EU (27 Member States) & 22,500 & 23,700 & 25,000 & 25,000 & 23,500 & 24,500 & 25,100 & 25,700 & 25,900 \\
\hline
\end{tabular}

Source: Eurostat (2015) 
Compared to Poland, Slovenia is one of the Central and Eastern European countries with the lowest proportion of banks under foreign ownership. However, international banking groups from Austria, Belgium, Italy, France, and some other countries have their stakes in most of the 10 largest Slovenian banks. As stated by the IMF (International Monetary Fund, 2012), reforming state-controlled banks would help revitalize the Slovenian banking sector.

According to the Bank of Slovenia's annual report (Banka Slovenije, 2013), the ownership structure of banks in Slovenia changed considerably in 2013, when the Republic of Slovenia recapitalized five banks and thus became their 100\% owner. On December 31, 2013, there were seven subsidiary banks and three branches in Slovenia under full foreign ownership in addition to three banks under majority domestic ownership. Only one bank had more than $10 \%$ foreign equity.

Like Poland, Slovenia also has a two-tier governance system. In Slovenia, corporate governance is regulated by a number of acts that have been amended and supplemented in response to changes in legislation, market conditions, and recent cases of good practice. In the last few years, corporate governance of state-owned companies and banks has been at the forefront of attention in Slovenia.

\subsection{Empirical Analysis}

\subsubsection{Corporate governance variables and indicators}

Table 3 shows the average values of independent variables for all the banks from Poland and Slovenia included in the analysis.

The average scores of variables and the indicators of corporate governance transparency show that Slovenia (0.55) achieved lower scores in the analysis than Poland (0.66). Poland achieved higher scores than Slovenia in all studied indicators with the exception of the indicator care for stakeholders, where Poland achieved an average score of 0.57 and Slovenia's average score was 0.61. Concerning the indicator commitment to corporate governance (CG), we can establish that Polish banks publish a special chapter dedicated to corporate governance and that Polish banks most frequently publish a statement of compliance with the CG code.

The analysis of the variables included in the control and audit indicator shows that the average score of disclosures is higher in Poland (0.65) than in Slovenia (0.62). Both countries had the highest average scores for (i) external audits, where banks disclose that their auditors are one of the four
Table 3. Variables and Indicators of Corporate Governance

\begin{tabular}{|c|c|c|c|}
\hline Indicator & Poland & $\begin{array}{l}\text { Slo- } \\
\text { venia }\end{array}$ & $\begin{array}{c}\text { Total } \\
\text { ave- } \\
\text { rage }\end{array}$ \\
\hline $\begin{array}{l}\text { Indicator 1: Commitment to } \\
\text { corporate governance (CG) }\end{array}$ & 0.52 & 0.38 & 0.45 \\
\hline Own CG code (OCE) & 0.00 & 0.00 & 0.00 \\
\hline Separate section on CG (SSN) & 0.71 & 0.69 & 0.70 \\
\hline $\begin{array}{l}\text { Statement of compliance } \\
\text { with the CG code (SCE) }\end{array}$ & 0.85 & 0.46 & 0.66 \\
\hline Indicator 2: Control and audit & 0.65 & 0.62 & 0.64 \\
\hline Internal audit department (IAD) & 0.91 & 0.99 & 0.95 \\
\hline Direct reporting of internal audit (DIR) & 0.61 & 0.99 & 0.80 \\
\hline Audit committee (AC) (ACD) & 0.82 & 0.57 & 0.70 \\
\hline Audit committee members (ACM) & 0.44 & 0.41 & 0.43 \\
\hline $\begin{array}{l}\text { Independent director of audit } \\
\text { committee (IDAC) }\end{array}$ & 0.54 & 0.20 & 0.37 \\
\hline External auditors-the Big 4 (AU4) & 0.98 & 0.97 & 0.98 \\
\hline Additional services of external auditor (EAAS) & 0.24 & 0.24 & 0.24 \\
\hline Indicator 3: Care for stakeholders & 0.57 & 0.61 & 0.59 \\
\hline $\begin{array}{l}\text { Representative of employees on } \\
\text { supervisory board (ERB) }\end{array}$ & 0.00 & 0.13 & 0.07 \\
\hline Company's support for CSR activities (SCS) & 0.93 & 0.94 & 0.94 \\
\hline Corporate social responsibility report (CSR) & 0.78 & 0.76 & 0.77 \\
\hline $\begin{array}{l}\text { Indicator 4: Characteristics of supervisory } \\
\text { board and management board }\end{array}$ & 0.64 & 0.47 & 0.56 \\
\hline $\begin{array}{l}\text { Independence of supervisory } \\
\text { board members (NID) }\end{array}$ & 0.63 & 0.51 & 0.57 \\
\hline $\begin{array}{l}\text { Independence of supervisory } \\
\text { board president (IDSB) }\end{array}$ & 0.45 & 0.24 & 0.35 \\
\hline $\begin{array}{l}\text { Membership / employment of } \\
\text { supervisory board members (MSB) }\end{array}$ & 0.72 & 0.61 & 0.67 \\
\hline $\begin{array}{l}\text { Assessment policy / procedure for } \\
\text { supervisory board members (ASB) }\end{array}$ & 0.34 & 0.11 & 0.23 \\
\hline Remuneration-supervisory board (RSB) & 0.92 & 0.73 & 0.83 \\
\hline $\begin{array}{l}\text { System of management board } \\
\text { members assessment (ABD) }\end{array}$ & 0.53 & 0.28 & 0.41 \\
\hline Remuneration of management board (RMB) & 0.92 & 0.82 & 0.87 \\
\hline $\begin{array}{l}\text { Indicator 5: Remuneration, ownership, related- } \\
\text { party transactions and the application of IFRS }\end{array}$ & 0.75 & 0.58 & 0.67 \\
\hline Remuneration-supervisory board (RES) & 0.95 & 0.73 & 0.84 \\
\hline Ownership-supervisory board (OWS) & 0.79 & 0.07 & 0.43 \\
\hline Remuneration-management board (RED) & 0.98 & 0.79 & 0.89 \\
\hline Ownership-management board (OWB) & 0.79 & 0.07 & 0.43 \\
\hline Related-party transactions (RPT) & 0.70 & 0.52 & 0.61 \\
\hline $\begin{array}{l}\text { Related-party transactions-supervisory } \\
\text { board and management board (RPM) }\end{array}$ & 0.45 & 0.49 & 0.47 \\
\hline Application of IFRS (IFRS) & 1.00 & 0.92 & 0.96 \\
\hline Ownership structure (OST) & 0.56 & 1.00 & 0.78 \\
\hline Variable compensation (VAC) & 0.49 & 0.59 & 0.54 \\
\hline Total-average & 0.66 & 0.55 & 0.61 \\
\hline
\end{tabular}


largest auditing firms (0.98), and (ii) internal audit, where banks disclose that they have an internal audit department (0.75). The least disclosed information was the one on the additional services (i.e., non-auditing services) provided to the banks by external auditors $(0.24)$.

Concerning the indicator care for stakeholders, Slovenia (0.61) scored better than Poland (0.57). Among the variables defining this indicator, the banks place the most emphasis on the disclosure of information about their support for socially responsible activities (0.94). Fewer banks have a special report or a special chapter on corporate social responsibility in their annual reports (0.77). The least attention is placed on the disclosure of whether the banks have a representative of employees on the supervisory board (0.07).

Regarding the variables constituting the indicator characteristics of supervisory board and management board, Poland achieved far better scores (0.64) than Slovenia (0.47). Most frequently, the banks disclose the information about the remuneration of individual members of their management boards and supervisory boards. In both cases, Poland had better scores (0.92) than Slovenia.

The remuneration, ownership, related-party transactions, and application of IFRS indicator showed that Poland (0.75) was again better than Slovenia (0.58). The banks most frequently disclose their application of IFRS (0.96). Looking at remuneration, we can see that the banks more transparently disclose the information about remuneration (by name or at the aggregate level) of their management boards (0.89) than of their supervisory boards (0.84). Again, Polish banks had better results in both cases than Slovenian ones. In most cases, the banks also disclosed their ownership structure in their annual reports for at least five of their major shareholders or for $90 \%$ or more of their ownership (0.78). Here, Slovenia had better results than Poland.

\subsubsection{Corporate governance index}

Table 4 shows the distribution of corporate governance index per distribution groups with index scores 0 , from 0 to 5 , from 5 to 10 , from 10 to 15 , from 15 to 20 , and from 20 to 25 (per frequency of the achieved scores). In both countries, the maximum index score that could be achieved was 29 and the minimum score was 0 . Poland is a country in which the density of banks with the highest index scores is bigger than in Slovenia; more than 52\% of all Polish banks included in this study belong to the 20-25 index score group. In Slovenia, the prevailing index score groups are the 10-15 and 15-20 groups. A vast majority of banks in Slovenia (83\%) reached an index score between 10 and 20.
Based the results obtained, we can state that corporate governance (as defined by the disclosure of the analyzed variables) is better in Poland than in Slovenia. It is characteristic for both countries that most banks achieved corporate governance index between 15 and 25 (74 cases in Poland and 47 cases in Slovenia).

Table 4. Distribution of Corporate Governance Index

\begin{tabular}{lccc} 
Index score & Poland & Slovenia & Average \\
\hline 0 & 1 & 0 & 1 \\
\hline from 0 to 5 & 2 & 1 & 2 \\
\hline from 5 to 10 & 1 & 5 & 3 \\
\hline from 10 to 15 & 12 & 37 & 25 \\
\hline from 15 to 20 & 27 & 38 & 33 \\
\hline from 20 to 25 & 47 & 9 & 28 \\
\hline from 25 to 29 & 0 & 0 & 0 \\
\hline
\end{tabular}

\subsubsection{Impact of corporate governance on bank performance}

We used regression analysis to investigate the impact of corporate governance on bank performance in Poland and Slovenia. We defined corporate governance using the corporate governance index and treated it as the independent variable in our model. The net interest income (NETII) is the indicator of banks' performance and is treated as the dependent variable. Our research hypothesis is: Corporate governance has an impact on bank performance.

Table 5. Correlation Coefficients Between Corporate Governance Index and NETII

NETII

\begin{tabular}{llll}
\hline \multirow{2}{*}{ Poland } & \multirow{2}{*}{ CG Index } & Pearson's correlation coefficient & 0.047 \\
\cline { 2 - 3 } & Sig. & 0.661 \\
\hline \multirow{2}{*}{ Slovenia } & CG Index & Pearson's correlation coefficient & $0.310^{* *}$ \\
\cline { 2 - 3 } & Sig. & 0.003 \\
\hline
\end{tabular}

Note: * Correlation is significant at the 0.05 level (2-tailed); ** Correlation is significant at the 0.01 level (2-tailed).

We assumed that a positive correlation exists between the corporate governance index and bank performance and that, with an increasing value of corporate governance index, bank performance, as measured with NETII, also increases. Based on the results obtained, we established that there is a positive correlation between the corporate governance index and NETII in both Poland (r=0.047; sig. 0.661) and Slovenia ( $\mathrm{r}=0.310$; sig. 0.01), but it is statistically significant in Slovenia only. We also performed a regression analysis for both countries to examine the impact of corporate governance on bank performance: 
$\operatorname{NETII}_{i t}=a_{1}+b_{1}$ Index $_{i t} C G+c_{1}$ Factor $_{j i t}+\varepsilon$

Bank performance (NETII) is a dependent variable in our model. We obtained the NETII values of banks in our sample from the Bankscope database. $a_{1}$ is the constant, and it tells us the value of NETII when the value of all other variables in the regression equation is $0 . b_{1}$ is the regression coefficient, where $i$ is the number of observations (i.e., 10 banks * 9 years), and $t$ are the years (i.e., 2005-2013). $c_{1}$ is the differential coefficient of constant $a_{1}$, which takes into account the impact of independent variables (i.e., the factors of institutional environment) on bank performance, where $j$ is an independent variable (a factor of institutional environment), $i$ is the number of observations, and $t$ are the years. $\varepsilon_{\text {it }}$ is the error term. The following factors of institutional environment were used in the regression analysis: (i) the rate of GDP per capita growth for the previous period (\%) for the country under analysis (GDPGR), (ii) the rule of law (RUOLAW), and (iii) government efficiency (GOVEFF).

In Tables 6a and 6b, we present the calculations of simple linear regression analyses and the impact of corporate governance index on bank performance. These two tables also show the results of regression analyses with the included factors of the institutional environment next to the corporate governance index.

Table 6a. Corporate Governance and Bank Performance, Poland

\begin{tabular}{|c|c|c|c|c|}
\hline \multirow{2}{*}{ Poland } & \multicolumn{4}{|c|}{ NETII } \\
\hline & $(1)$ & $(2)$ & (3) & $(4)$ \\
\hline CG Index & 20.813 & 8.937 & -8.684 & -3.514 \\
\hline Significance level & 0.661 & 0.852 & 0.858 & 0.942 \\
\hline$t$-value & 0.440 & 0.187 & -0.180 & -0.073 \\
\hline GDPGR & & -34.862 & & \\
\hline Significance level & & 0.153 & & \\
\hline$t$-value & & -1.441 & & \\
\hline RUOLAW & & & 626.188 & \\
\hline Significance level & & & 0.031 & \\
\hline$t$-value & & & 2.194 & \\
\hline GOVEFF & & & & 786.522 \\
\hline Significance level & & & & 0.044 \\
\hline$t$-value & & & & 2.043 \\
\hline The constant & 478.455 & 615.016 & 111.809 & 29.244 \\
\hline Significance level & 0.000 & 0.000 & 0.519 & 0.896 \\
\hline$t$-value & 10.939 & 5.900 & 0.648 & 0.131 \\
\hline $\mathrm{R}^{2}$ & 0.002 & 0.026 & 0.055 & 0.048 \\
\hline $\mathrm{N}$ & 89 & 89 & 89 & 89 \\
\hline
\end{tabular}

Corporate governance index, as the most important, independent variable, was included in the first regression model. We found that it has a positive impact on bank performance (measured with NETII) in both Poland and Slovenia. We also found that this impact is statistically significant in Slovenia (32.743; $t=3.064$, sig. 0.003). This result is in accordance with our expectations that a higher corporate governance index and the related better disclosures of corporate governance in annual reports have a positive impact on bank performance. Based on these results, we can confirm our hypothesis that corporate governance has an impact on bank performance and that this impact is positive.

For the second regression model, we used corporate governance index and the variable GDP growth per capita (GDPGR). When measuring bank performance with NETII, we established that the regression coefficient $b_{2}$ was not statistically significant in either of the two countries.

The third regression model included the corporate governance index and the variable RUOLAW (i.e., the rule of law in a given country in a given year). This variable stands for the extent to which there is trust in and compliance with the rules and laws, the police, and the courts. A higher score means more respect of the law and successful work in this area, while a lower score means less respect for the principles of law, its bodies, and their work. Our study of the impact of

Table 6b. Corporate Governance and Bank Performance, Slovenia

\begin{tabular}{|c|c|c|c|c|}
\hline \multirow{2}{*}{ Slovenia } & \multicolumn{4}{|c|}{ NETII } \\
\hline & (1) & (2) & (3) & (4) \\
\hline CG Index & 32.743 & 41.427 & 41.693 & 32.832 \\
\hline Significance level & 0.003 & 0.001 & 0.002 & 0.004 \\
\hline$t$-value & 3.064 & 3.422 & 3.196 & 2.958 \\
\hline GDPGR & & 4.159 & & \\
\hline Significance level & & 0.139 & & \\
\hline$t$-value & & 1.492 & & \\
\hline RUOLAW & & & -189.844 & \\
\hline Significance level & & & 0.237 & \\
\hline$t$-value & & & -1.190 & \\
\hline GOVEFF & & & & -4.088 \\
\hline Significance level & & & & 0.975 \\
\hline$t$-value & & & & -0.032 \\
\hline The constant & 89.928 & 85.030 & 273.635 & 94.120 \\
\hline Significance level & 0.000 & 0.000 & 0.080 & 0.475 \\
\hline$t$-value & 8.462 & 7.693 & 1.769 & 0.718 \\
\hline $\mathrm{R}^{2}$ & 0.096 & 0.119 & 0.111 & 0.096 \\
\hline $\mathrm{N}$ & 90 & 90 & 90 & 90 \\
\hline
\end{tabular}


RUOLAW on bank performance (expressed through NETII) showed that this impact is positive and statistically significant for Poland (626.188; $t=2.194$, sig. 0.031). This means that trust in the agents and their respect of the rules, laws, and the authorities have a positive impact on bank performance. This variable additionally explains the $5.3 \%$ of the variability in banks’ performance.

In the fourth regression model, we added the variable GOVEFF (i.e., government efficiency) to the corporate governance index. GOVEFF mainly covers the quality of public services, the degree of independence from political pressure, and the quality of policy formulation and implementation. The impact on NETII is positive and statistically significant for Poland (786.522, $t=2.043$, sig. 0.044). This variable explains an additional $4.6 \%$ of the variability in banks' performance. The scores obtained for Slovenia were not statistically significant.

\section{Discussion and Conclusion}

In this paper, we studied the characteristics of corporate governance in banks in Poland and Slovenia between 2005 and 2013. We also examined the impact of corporate governance of these banks on their performance. Similar to the findings of other authors, this contribution showed that there are both similarities and differences between banks and countries in regard to the characteristics of corporate governance. Corporate governance also influences bank performance in different ways.

The results of our analysis demonstrated that the total average of all variables and indicators of the quality of corporate governance transparency was lower in Slovenia (0.55) than in Poland (0.66). Poland actually reached higher average scores than Slovenia regarding all indicators except for the indicator care for stakeholders, where Slovenia's average score was 0.61 and the Polish one was 0.57 . Poland has the highest density of banks with the highest corporate governance index scores. The regression analysis enabled us to investigate the impact of corporate governance on bank performance in Poland and Slovenia. We defined corporate governance using the corporate governance index, which we treated as the independent variable in our regression model. We used the banks' net interest income (NETII) as the indicator of their performance and treated it as the dependent variable. Based on the results of the regression analysis, we established that corporate governance has an impact on bank performance, with this impact being positive in both countries and statistically significant in Slovenia. The following factors of the institutional environment were also used in the regression analysis: (i) the rate of GDP growth per capita from the previous period (in\%) for each country under investigation (GDPGR), (ii) the rule of law (RUOLAW), and (iii) government efficiency (GOVEFF). The impact of GDP growth per capita was not statistically significant in either of the countries. The rule of law (RUOLAW) and the impact of government efficiency (GOVEFF) had a positive and statistically significant impact in Poland.

This paper raised a number of questions that still have to be answered, offering possibilities for further research. Further studies might focus on similar analyses of substantive and qualitative aspects of corporate governance and on the search for the causes for their differences. Apart from the investigation of the impact of corporate governance and other variables included in the present research on bank performance, future research should include additional variables that may have an influence on either corporate governance or bank performance. Other bank performance measurements could also be included. Regarding research methodology, some other methodological approaches and analyses could be undertaken to study this topic. Future investigations could focus on the analysis of a similar type of banks; they should be performed on a larger sample and should consider a longer time span.

\section{References}

1. Adams, R., \& Mehran, H. (2008). Corporate performance, board structure, and their determinants in the banking industry. Retrieved from http://www.nyfedeconomists.org/research/staff_reports/sr330.pdf. http://dx.doi.org/10.2139/ssrn.1150266

2. Alexander, K. (2010). The banking crisis: Regulation and supervision. In J. MacNeil \& I. O'Brien (Eds.), The future of financial regulation (pp. 437-444). Portland: Hart Publishing.

3. Arhar, F. (2008). Upravljanje korporacij. Bančni vestnik, 1-2, 40-44.

4. Baek, J., Kang, J., \& Park, K. (2004). Corporate governance and firm value: evidence from the Korean financial crisis. Journal of Financial Economics, 71(2), 265-313. http://dx.doi.org/10.1016/S0304-405X(03)00167-3

5. Banka Slovenije. (2013). Letno Poročilo 2013. Ljubljana: Banka Slovenije. Retrieved from https://www.bsi.si/iskalniki/letna_porocila. asp?Mapald=709

6. Basel Committee on Banking Supervision. (2006). Enhancing Corporate governance for banking organisations. Retrieved from http://www.bis.org/publ/bcbs122.pdf

7. Basel Committee on Banking Supervision. (2010). Principles for enhancing Corporate Governance. Retrieved from http://www.bis.org/publ/bcbs176.pdf 
8. Caprio, G., \& Levine, R. (2002). Corporate governance of banks: Concepts and international observations. In R. Litan, M. Pomerleano, \& V. Sundararajan (Eds.), Financial sector governance: The roles of the public and private sectors (pp.17-50). Washington, DC: Brookings Institution Press.

9. Curtiss, F., Levine, I., \& Browning, J. (2010). The institutional investor's role in "responsible ownership." In I. MacNeil \& J. O'Brien (Eds.), The future of financial regulation (pp. 301-313). Portland: Hart Publishing.

10. European Banking Authority. (2015). Aggregate statistical data 2007-2013. Retrieved from http://www.eba.europa.eu/supervisory-convergence/supervisory-disclosure/aggregate-statistical-data

11. Eurostat. (2015). National accounts database. Retrieved from http://ec.europa.eu/eurostat/data/database

12. Guo, R., Langston, V., \& Hadley, L. (2012). Business cycle, corporate governance, and bank performance. Research in Business and Economics Journal, 5, 1-11.

13. International Monetary Fund. (2012). Republic of Slovenia: Financial system stability assessment. Retrieved from https://www.imf.org/external/pubs/ft/scr/2012/cr12325.pdf

14. Kirkpatrick, G. (2009). The corporate governance lessons from the financial crisis. Retrieved from http://www.oecd.org/finance/financial-markets/42229620.pdf. http://dx.doi.org/10.1787/fmt-v2009-art3-en

15. La Porta, R., Lopez-de-Silanes, F., Shleifer, A., \& Vishny, R. (1998). Law and finance. Journal of Political Economy, 106(6), $1113-1155$. http://dx.doi.org/10.1086/250042

16. Levine, R. (2004). Finance and growth: Theory and evidence. Retrieved from http://www.nber.org/papers/w10766.pdf

17. Lloyd, B. (2009). Governance models lessons from the global crisis? Accountancy Ireland, 41(6), 43-45. Retrieved from http://www.accountancyireland.ie/

18. Love, I., \& Rachinsky, A. (2007). Corporate governance, ownership and bank performance in emerging markets: Evidence from Russia and Ukraine. Retrieved from http://siteresources.worldbank.org/DEC/Resources/Corporate_Governnace_Ownership_and_Bank_Performance.pdf

19. Organisation for Economic Cooperation and Development. (2009). Načela korporativnega upravljanja OECD. Retrieved from http://www.mg.gov.si/fileadmin/mg.gov.si/pageuploads/DEOT/NACELA_OECD.pdf

20. Pawłowska, M. (2014). On competition in the banking sector in Poland and Europe before and during the crisis. Retrieved from http://papers.ssrn.com/sol3/papers.cfm?abstract_id=2550678. http://dx.doi.org/10.2139/ssrn.2550678

21. Selvaggi, M., \& Upton,J. (2008). Governance and performance in corporate Britain: Evidence from the IVIS colour-coding system. Retrieved from http://www.accountability-central.com/uploads/media/GovernanceAndPerformancelnCorporateBritan.pdf

22. Słomka-Gołębiowska,A., \& Urbanek, P. (2014). Executive remuneration policy at banks in Poland after the financial crisis-Evolution or revolution? Comparative Economic Research, 17(2). Retrieved from http://www.degruyter.com/view/j/cer.2014.17.issue-2/cer-2014-0012/cer-2014-0012.xml

23. The World Bank. (2005). Report on the observance of standards and codes (ROSC)-Poland. Retrieved from http://www.worldbank.org/ifa/rosc_cg_pol_05.pdf

24. Tomasic, R. (2010). Beyond "light touch" regulation of British banks after the financial crisis. In V I. MacNeil \& J. O'Brien (Eds.), The future of financial regulation (pp. 103-122). Portland: Hart Publishing.

25. Utama, C., \& Musa, H. (2011). The causality between corporate governance practice and bank performance: Empirical evidence from Indonesia. Gadjah Mada International Journal of Business, 13(3), 227-247.

\section{Authors}

Polona Pašić holds a Ph.D. degree in economics and business sciences from the Faculty of Economics and Business, University of Maribor. She earned her bachelor's degree in economics from the Faculty of Economics, University of Ljubljana, where she graduated with distinction.

Borut Bratina, Ph.D., is an associate professor of law at the Department of Business Law at the Faculty of Economics and Business, University of Maribor. He is the head lecturer for a number of courses in business law within undergraduate and postgraduate study programs at the Faculty of Economics and Business (FEB) and other faculties of the University of Maribor. He is the head of the Institute of Business Law at FEB and a co-founder of the Institute for Economic and Corporate Governance (IECG Maribor). His scientific and professional focus is in the field of corporate law and corporate governance.

Mejra Festić, Ph.D., is a full professor of economic systems, economic policy and economic theory, and the application of econometrical analysis. She is also an associate professor of banking and finance. Since March 1, 2011, she has been a vice governor of the Bank of Slovenia; she is currently its deputy governor. Her research fields cover monetary systems, monetary economics, banking and finance, macroprudential and systemic risk, financial stability, economic policies, economic theory, macroeconomics, the application of econometrical methodologies, and the appraisal of economic efficiency of investment projects at macro and micro levels. 


\section{Korporativno upravljanje bank na Poljskem in v Sloveniji}

\section{Izvleček}

V članku se osredotočamo na proučevanje značilnosti korporativnega upravljanja $\vee$ bankah na Poljskem in v Sloveniji, in sicer v obdobju med letoma 2005 in 2013 . Proučen je tudi vpliv korporativnega upravljanja teh bank na njihovo poslovanje. Rezultati opravljene raziskave kažejo, da je Slovenija dosegla nižje povprečne vrednosti spremenljivk in kazalnikov kakovosti transparentnosti korporativnega upravljanja kot Poljska. Gostota bank z doseženimi najvišjimi vrednostmi indeksa korporativnega upravljanja je na Poljskem prav tako večja kot v Sloveniji. Pri proučevanju vpliva korporativnega upravljanja na uspešnost poslovanja bank, ki jo merimo z neto obrestnimi prihodki, z regresijsko analizo ugotavljamo, da je ta vpliv pozitiven v obeh državah in statistično značilen v Sloveniji.

Ključne besede: korporativno upravljanje, uspešnost bank, Srednja in Vzhodna Evropa, indeks korporativnega upravljanja, neto obrestni prihodek. 